\title{
A Study of Mathematics Teachers' Motivation towards Teaching in Brunei Darussalam
}

\author{
Hjh Naziah Sahat \\ Rimba Secondary School, Ministry of Education, Brunei Darussalam \\ E-mail: naziah.sahat@rimba.moe.gov.bn \\ Adina Yantiaryanie Hj A. Abd. Rahman \\ Orang Kaya SetiaBaktiKilanas Primary School, Ministry of Education, Brunei Darussalam \\ E-mail: deena188@hotmail.com
}

\begin{abstract}
Khairul Amilin Tengah
Sultan HassanalBolkiahInstutite of Education, Universiti Brunei Darussalam

JalanUniversiti, BE 1410, Brunei Darussalam

E-mail: khairul.tengah@ubd.edu.bn

Hui-Chuan Li (Corresponding Author)

Sultan HassanalBolkiahInstutite of Education, Universiti Brunei Darussalam

JalanUniversiti, BE 1410, Brunei Darussalam

E-mail: huichuan.li@ubd.edu.bn

Nor Azura Abdullah

Sultan HassanalBolkiahInstutite of Education, Universiti Brunei Darussalam JalanUniversiti, BE 1410, Brunei Darussalam

E-mail: azura.abdullah@ubd.edu.bn
\end{abstract}

Received: Feb. 28, 2018 Accepted: April 9, $2018 \quad$ Published: May 1, 2018

doi:10.5296/jse.v8i2.12732 URL: https://doi.org/10.5296/jse.v8i2.12732 


\begin{abstract}
Many factors contribute to the success of students' academic performance. Admittedly, quality of teaching is one of those factors. In this study, based on the related literature on teacher motivation, six main factors affecting teachers' motivation towards teaching are identified. Accordingly, an online questionnaire was designed by the authors. In total, 207 (40 males and 167 females) mathematics teachers from primary, secondary and sixth-form government schools in Brunei Darussalam randomly volunteered to respond to this questionnaire. The findings from this study have implications for understanding the extent to which factors may motivate or demotivate teachers to teach. The present research provided education stakeholders with important information to ponder over the motivational factors of mathematics teachers in the government schools. The results from our study also suggested that good interaction and collaboration between teachers can help boost teachers' motivation to teach.
\end{abstract}

Keywords: Teacher motivation towards teaching; motivational factors; Brunei Darussalam; mathematics teacher 


\section{Introduction}

Many factors contribute to the success of students' academic performance. Admittedly, quality of teaching is one of those factors. Michaelowa (2002) pointed out that the quality of teaching is largely associated with teachers' motivation towards teaching. It was also found that motivated teachers can be linked with an increase in students' achievement (Atkinson, 2000). Many studies have been conducted on the motivational level of teachers. Synthesizing from those studies, six main factors affecting teachers' motivation towards teaching are identified and stated as follow:

\subsection{Salary and Benefits}

It has been found that an increase in salary and benefits will increase a person's motivation (Chiu, 2000). Ghenghesh (2013) provided evidence to show that teachers would be dissatisfied in their salary if the amount of salary given is not adequate with the effort and time that have been put in and this lead to frustration.

\subsection{Opportunities for Continuous Professional Development}

Guajardo (2011) pointed out that professional development plays an important role in enhancing teachers' motivation, and that shortage of career development opportunities contribute to lack of motivation among educators.

\subsection{Support from School}

Research also shows that teachers will be more satisfied in their job if their job provides opportunities for professional advancement and this needs support from the school authority (Urwick, Mapuru \& Nkhoboti, 2005).

\subsection{Collaboration with Colleagues}

Colleagues' support has been identified a factor that influences teacher's motivation to excel in their performance (Rasheed \& Aslam, 2010). Working with supportive colleagues can channel teachers toward high quality performance (Ghenghesh, 2013). There is little doubt that good collaboration with colleagues can help increase teacher motivation towards teaching (Sargent \& Hannum, 2005).

\subsection{Involvement in the Decision of School Policy}

Leaders who give empowerment to their employees are claimed to be one of the most powerful reinforces in building their employees' motivation (Seniwoliba, 2013). It was found that, when teachers are involved in decision making, it can help trigger teachers' motivation (Short, Greer, \& Melvin, 1994).

\subsection{Students' Commitment to Learning}

There is little doubt that teaching quality is closely associated with students' commitment to learning (Guajardo, 2011). Students' commitment enhances teachers' motivation to continue teaching, particularly upon seeing students' success, which makes teachers feel that they fulfill their own personal accomplishment (Dörnyei \& Ushioda, 2011; Li, 2012). Herzberg, 


\section{NI Macrothink}

Journal of Studies in Education

ISSN 2162-6952

2018, Vol. 8, No. 2

Mausner, and Snyderman (2010) asserted that student achievement is an intrinsic motivator which stimulate a teacher's motivation to put in his/her best effort.

\section{Purpose of the Study}

There have been numerous studies conducted on teachers' motivation in different countries across the world, but little research was done to investigate mathematics teachers' motivation towards teaching in Brunei Darussalam. Therefore, this study sought to investigate whether or not the six aforementioned factors affect Bruneian mathematics teachers' motivation towards teaching. This research also helped shed light on how these factors affected teachers' motivation in the context of Brunei Darussalam.

\section{Methods}

\subsection{Participants}

In total, 207 (40 males and 167 females) mathematics teachers from primary, secondary and sixth-form government schools in Brunei Darussalam randomly volunteered to take part in this study. Table 1 shows the teaching experience of the participating teachers.

Table 1. Teaching experience of the teachers

\begin{tabular}{ll}
\hline Teaching experience in years & Number of respondents $(\mathrm{N}=207)$ \\
\hline 5 years or less & 39 \\
$6-10$ years & 59 \\
$11-15$ years & 61 \\
$16-20$ years & 27 \\
21 years or more & 21 \\
\hline
\end{tabular}

\subsection{Instrument}

Synthesized from the related literature on teacher motivation, an online questionnaire was designed by the authors. The questionnaires consisted of two sections: (1) Section A: mathematic teachers' demographic information and (2) Section B: the six factors affecting teachers' motivation towards teaching (using a 5-point Likert scale). The data gathered from the questionnaire in this study was analyzed using descriptive statistics.

\section{Results and discussion}

Below are the analyses of the participants' responses to the items relating to the six aforementioned factors that might affect mathematics teachers' motivation towards teaching.

\subsection{Factor 1: Salary and Benefit}

Four items were measured under Factor 1 (Table 2). More than half of them agreed or strongly agreed that the salary received was equivalent with their qualification. Also, a high percentage of teachers agreed or strongly agreed that their salary was reasonable with the amount of work they did. Overall, the mathematics teachers were satisfied with the salary that they received but they argued that additional benefits needed to be considered to increase or 
continue their motivation. For example, many teachers spent quite a lot in their teaching aids at their own expenses.

Table 2. Respondents' views on salary and benefits

\begin{tabular}{|c|c|c|c|c|c|c|}
\hline \multirow{2}{*}{ Items } & \multicolumn{6}{|c|}{ Percentage Responses \% $(\mathrm{N}=207)$} \\
\hline & SA & A & $\mathrm{N}$ & $\mathrm{D}$ & SD & NR \\
\hline $\begin{array}{l}\text { 1(a) My salary is equivalent to my } \\
\text { qualification. }\end{array}$ & 16.4 & 44.4 & 17.4 & 9.66 & 4.35 & 7.73 \\
\hline $\begin{array}{l}\text { (b) My salary is reasonable for the } \\
\text { amount of work I do. }\end{array}$ & 7.25 & 34.8 & 24.6 & 17.9 & 7.73 & 7.73 \\
\hline $\begin{array}{l}\text { 1(c) Pay incentives would improve } \\
\text { my morale as a teacher. }\end{array}$ & 43.0 & 31.4 & 14.5 & 2.90 & 0.48 & 7.73 \\
\hline $\begin{array}{l}\text { 1(d) Employee benefits (e.g. } \\
\text { teaching aids allowance) should be } \\
\text { given to teachers. }\end{array}$ & 61.8 & 26.6 & 2.42 & 0.97 & 0.48 & 7.73 \\
\hline
\end{tabular}

Note. $\mathrm{SA}=$ Strongly Agree; $\mathrm{A}=$ Agree; $\mathrm{N}=$ Neutral; $\mathrm{D}=$ Disagree; $\mathrm{SD}=$ Disagree; $\mathrm{NR}=$ No Response

\subsection{Factor 2: Opportunities for Continuous Professional Development}

Three items were related to Factor 2 (Table 3). It showed that generally, teachers are satisfied with the career development they ventured, suggesting that they valued and appreciated the opportunities for further professional development.

Table 3. Respondents' views on opportunities for continuous professional development

\begin{tabular}{|c|c|c|c|c|c|c|}
\hline \multirow{2}{*}{ Items } & \multicolumn{6}{|c|}{ Percentage Responses \% $(\mathrm{N}=207)$} \\
\hline & SA & $\mathrm{A}$ & $\mathrm{N}$ & $\mathrm{D}$ & SD & NR \\
\hline $\begin{array}{l}\text { 2(a) Professional developments are } \\
\text { much beneficial for me. }\end{array}$ & 18.4 & 46.4 & 23.2 & 2.90 & 1.45 & 7.73 \\
\hline $\begin{array}{l}\text { 2(b) There is potential for advancement } \\
\text { (e.g. possibility of pursuing } \\
\text { different positions in the profession). }\end{array}$ & 6.76 & 36.7 & 29.5 & 12.1 & 7.25 & 7.73 \\
\hline $\begin{array}{l}\text { 2(c) There is an equal chance given to } \\
\text { me to attend professional development } \\
\text { programs in order to enhance my } \\
\text { professional skills. }\end{array}$ & 6.28 & 43.5 & 29.5 & 10.6 & 2.42 & 7.73 \\
\hline
\end{tabular}

Note. $\mathrm{SA}=$ Strongly Agree; $\mathrm{A}=$ Agree; $\mathrm{N}=$ Neutral; $\mathrm{D}=$ Disagree; $\mathrm{SD}=$ Disagree; $\mathrm{NR}=$ No Response

\subsection{Factor 3: Support from School}

Nine items were related to the third factor (Table 4). $28.46 \%$ of the participating teachers felt that they were given enough resources to be utilized. However, $29.51 \%$ of them considered that they could not maximize their teaching abilities since the schools were lacking resources. It is important to note here that availability of resources is crucial, since schools with ample 
resources would improve teachers' motivation (Sargent \& Hannum, 2005). Based on the teachers' responses to the items regarding the support that they received from school, overall, they were generally satisfied with the school support in terms of the environment, recognition, promotion, their empathy and initiative to handle classroom problems faced by teachers.

Table 4. Respondents' perception on support from school

\begin{tabular}{|c|c|c|c|c|c|c|}
\hline \multirow{2}{*}{ Items } & \multicolumn{6}{|c|}{ Percentage Responses \% $(\mathrm{N}=207)$} \\
\hline & SA & $\mathrm{A}$ & $\mathrm{N}$ & $\mathrm{D}$ & SD & NR \\
\hline $\begin{array}{l}\text { 3(a) I am given sufficient resources to } \\
\text { utilize my teaching abilities. }\end{array}$ & 3.86 & 24.6 & 22.2 & 24.2 & 5.31 & 19.8 \\
\hline $\begin{array}{l}\text { 3(b) The school administration provides } \\
\text { an environment where we as } \\
\text { teachers from diverse background can } \\
\text { work together effectively. }\end{array}$ & 6.28 & 36.7 & 23.2 & 10.1 & 3.86 & 19.8 \\
\hline $\begin{array}{l}\text { 3(c) The school administration has } \\
\text { empathy towards the teachers. }\end{array}$ & 5.80 & 29.5 & 27.5 & 10.1 & 7.25 & 19.8 \\
\hline $\begin{array}{l}\text { 3(d) I have very good relationship with } \\
\text { the school administration. }\end{array}$ & 8.70 & 38.7 & 25.6 & 5.31 & 1.93 & 19.8 \\
\hline $\begin{array}{l}3(\mathrm{e}) \text { I do get recognized for my } \\
\text { achievements by the school } \\
\text { administration. }\end{array}$ & 6.28 & 23.2 & 31.9 & 12.6 & 6.28 & 19.8 \\
\hline 3(f) The recognition process is not bias. & 3.38 & 25.6 & 32.9 & 13.5 & 4.83 & 19.8 \\
\hline $\begin{array}{l}3(\mathrm{~g}) \text { The promotion process is based on } \\
\text { performance. }\end{array}$ & 4.35 & 33.8 & 26.1 & 10.6 & 5.31 & 19.8 \\
\hline $\begin{array}{l}3(\mathrm{~h}) \text { The performance evaluation } \\
\text { program is fair. }\end{array}$ & 2.42 & 16.9 & 36.7 & 14.0 & 10.1 & 19.8 \\
\hline $\begin{array}{l}\text { 3(i) If I have problems in my classroom } \\
\text { which are beyond my capability } \\
\text { to handling them, the school } \\
\text { administration takes the initiative to } \\
\text { discuss the matter. }\end{array}$ & 5.31 & 32.9 & 26.6 & 12.1 & 3.38 & 19.8 \\
\hline
\end{tabular}

Note. $\mathrm{SA}=$ Strongly Agree; $\mathrm{A}=$ Agree; $\mathrm{N}=$ Neutral; $\mathrm{D}=$ Disagree; $\mathrm{SD}=$ Disagree; $\mathrm{NR}=$ No Response

\subsection{Factor 4: Collaboration with colleagues}

Table 5 shows the results of five items regarding Factor 4. It is seen that more than half of the respondents had a positive view on the collaboration with their colleagues, in which they considered that they had good communication with others and were given emotional support whenever needed. While not all schools had mentor-mentee system, they still managed to form a good teamwork since, as shown in Table 5, 58\% of them agreed that teamwork existed among colleagues. This may suggest that mathematics teachers were willing to work and collaborate with colleagues. 
Table 5. Respondents' views on collaboration with colleagues

\begin{tabular}{lllllll}
\hline \multirow{2}{*}{ Items } & \multicolumn{7}{l}{ Percentage Responses \% (N=207) } \\
\cline { 2 - 7 } & SA & A & N & D & SD & NR \\
\hline $\begin{array}{l}\text { 4(a) I am treated fairly by my } \\
\text { colleagues. }\end{array}$ & 13.5 & 46.4 & 15.0 & 3.38 & 1.93 & 19.8 \\
$\begin{array}{l}\text { 4(b) I have good interaction with other } \\
\text { teachers. }\end{array}$ & 15.0 & 53.1 & 11.1 & 0.48 & 0.48 & 19.8 \\
$\begin{array}{l}\text { 4(c) I am given emotional support when } \\
\text { needed. }\end{array}$ & 8.70 & 44.9 & 20.8 & 2.90 & 2.90 & 19.8 \\
$\begin{array}{l}\text { 4(d) Teamwork exists among } \\
\text { colleagues. }\end{array}$ & 11.6 & 46.4 & 14.0 & 4.35 & 3.86 & 19.8 \\
$\begin{array}{l}\text { 4(e) There is mentor-mentee system in } \\
\text { my department. }\end{array}$ & 4.35 & 35.3 & 23.2 & 12.6 & 4.83 & 19.8 \\
\hline
\end{tabular}

Note. $\mathrm{SA}=$ Strongly Agree; $\mathrm{A}=$ Agree $\mathrm{N}=$ Neutral; $\mathrm{D}=$ Disagree; $\mathrm{SD}=$ Disagree; $\mathrm{NR}=$ No Response

\subsection{Factor 5: Involvement in the decision of school policy}

Five items focused on Factor 5: under involvement in the decision of school policy (Table 6). It should be noted that more than a quarter of the participants did not respond to this factor. However, based on the findings of this study, about a third of the respondents considered that they were given opportunities to voice out their opinions and are given the autonomy to make decisions. As shown in Table 6 in terms of the items 5(c) and 5(d), it suggested that fairly high number of the teachers were allowed to participate in school matters regarding academic, administration, or both. Result also showed that some mathematics teachers were involved in the decision of school policy.

Table 6. Respondents' views on involvement in the decision of school policy

\begin{tabular}{|c|c|c|c|c|c|c|}
\hline \multirow{2}{*}{ Items } & \multicolumn{6}{|c|}{ Percentage Responses \% $(\mathrm{N}=207)$} \\
\hline & SA & A & $\mathrm{N}$ & $\mathrm{D}$ & $\mathrm{SD}$ & NR \\
\hline $\begin{array}{l}\text { 5(a) I am given the freedom to voice out } \\
\text { my opinions. }\end{array}$ & 3.38 & 36.2 & 20.8 & 9.18 & 3.86 & 26.6 \\
\hline $\begin{array}{l}\text { 5(b) My ideas are taken into } \\
\text { consideration. }\end{array}$ & 2.42 & 29.5 & 29.0 & 9.18 & 3.38 & 26.6 \\
\hline $\begin{array}{l}5(\mathrm{c}) \text { The school administration and } \\
\text { teachers work together on the } \\
\text { school development plan. }\end{array}$ & 4.35 & 31.9 & 21.2 & 11.1 & 4.83 & 26.6 \\
\hline $\begin{array}{l}\text { 5(d) I am given the opportunity to } \\
\text { participate in teacher projects } \\
\text { (e.g. research, curriculum development). }\end{array}$ & 3.38 & 27.5 & 29.5 & 8.21 & 4.83 & 26.6 \\
\hline $\begin{array}{l}5(\mathrm{e}) \text { I am satisfied with the autonomy I } \\
\text { am given in making decisions about my } \\
\text { daily tasks. }\end{array}$ & 4.35 & 30.4 & 27.5 & 7.73 & 3.38 & 26.6 \\
\hline
\end{tabular}


Note. $\mathrm{SA}=$ Strongly Agree; $\mathrm{A}=$ Agree; $\mathrm{N}=$ Neutral; $\mathrm{D}=$ Disagree; $\mathrm{SD}=$ Disagree; $\mathrm{NR}=$ No Response

\subsection{Factor 6: Students’ Commitment to Learning}

As shown in Table 7, 69.5\% of the respondents agreed or strongly agreed that student success seemed to be the driver to keep them motivated to teach and $42.03 \%$ of them considered that majority of their students behaved well in class. However, from the respondents' responses to the items 6(c) and 6(d), it showed that many teachers selected either "Neutral" or "Disagree", suggesting that they were not satisfied with the extent of the commitment from students and cooperation from parents. It should be noted that more than a quarter of the participants avoided responding this factor, thus the result is based on those who responded.

Table 7. Respondents' views on students' commitment to learning

\begin{tabular}{lllllll}
\hline \multirow{2}{*}{ Items } & \multicolumn{7}{l}{ Percentage Responses \% (N=207) } \\
\cline { 2 - 7 } & SA & A & N & D & SD & NR \\
\hline $\begin{array}{l}\text { 6(a) Student success motivates me to } \\
\text { keep on teaching. }\end{array}$ & 44.4 & 25.1 & 2.90 & 0.00 & 0.97 & 26.6 \\
$\begin{array}{l}\text { 6(b) Majority of my students behave } \\
\text { well in class. }\end{array}$ & 7.73 & 34.3 & 14.0 & 14.0 & 3.38 & 26.6 \\
$\begin{array}{l}\text { 6(c) My students always complete the } \\
\begin{array}{l}\text { work(s) given on time. } \\
\text { 6(d) I am given full support from }\end{array} \\
\text { parents. }\end{array}$ & 1.93 & 14.5 & 20.3 & 30.4 & 6.28 & 26.6 \\
\hline
\end{tabular}

Note. $\mathrm{SA}=$ Strongly Agree; $\mathrm{A}=$ Agree; $\mathrm{N}=$ Neutral; $\mathrm{D}=$ Disagree; $\mathrm{SD}=$ Disagree; $\mathrm{NR}=$ No Response

\section{The Single Most Important Factor Affecting Teacher Motivation}

In this study, it was acknowledged that in addition to some inevitable constraints, such as time and expense, the scope of this study was limited by one key factor, which was the response rate. Only 130 out of 207 respondents completely answered all questions in this online questionnaire. As shown in Tables 2-7, the percentage of no response increased when the respondents answered the questions from Factor 1 to Factor 6. Moreover, by the end of the questionnaire, when the respondents were asked to answer this question: "What is the single most important area to increase your motivation as a teacher?", 67 (37\%) respondents did not answer this question, which was the lowest response rate as compared by other questions (see Tables 2-7). It suggested that partly because this was an online questionnaire, a number of respondents started the questionnaire, but they did not finish it. For example, if respondents did not answer the required questions, they would not be allowed to continue to the next page, which might make them to quit from answering the questionnaire and consequently, the response rate decreased from Factor 1 to Factor 6.

Nevertheless, it is worth mentioning that in this last question, $20 \%$ of the respondents considered salary as the first most important factor that may affect their motivation as 


\section{Macrothink}

teachers (Figure 1), while the percentage of choosing "others" was slightly lower as the second most important factor. This implies that salary plays an important role in motivating teachers towards teaching. The result is consistent with the findings of Seniwoliba (2013) that salary was considered to be the most important factor that would affect teacher motivation.

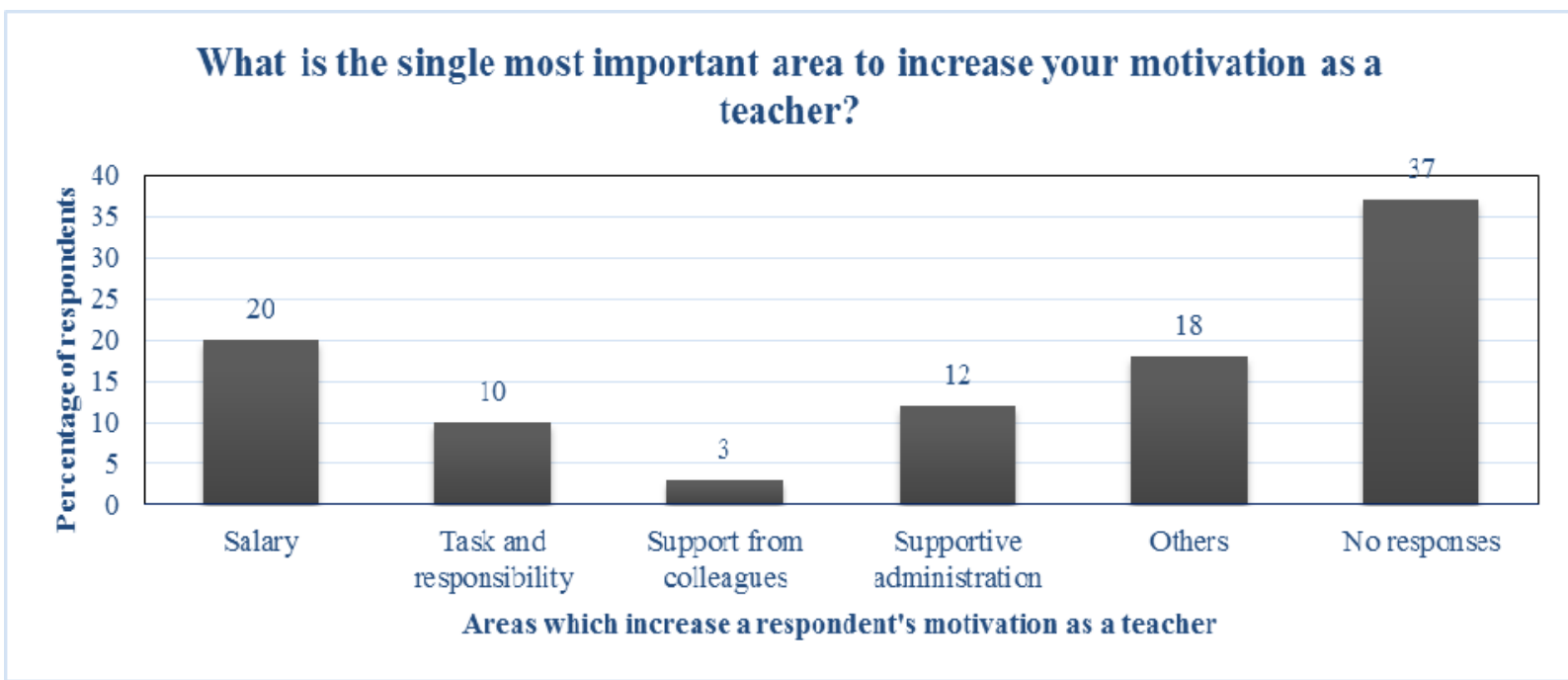

Figure 1. Respondents' views on the most important factor affecting teacher motivation

\section{Implications}

While the findings from the analysis undertaken in this study are subject to the limitations of the methodology used, some valuable insights into the current emotional state of mathematics teachers and the factors that motivated them were not invalidated. The findings from this study have implications for understanding the extent to which factors may motivate or demotivate teachers to teach. The present research has provided education stakeholders with important information to ponder over the motivational factors of mathematics teachers in the government schools. It is important for education stakeholders to make continuous efforts to sustain or boost teachers' motivation. Therefore, the productivity and effectiveness of student learning can be enhanced.

It should be highlighted that monetary incentives is the highest motivating factors based on results from 1(c), and "salary" as single most important factor. Other form of incentive such as benefit or allowances are also welcomed. Question remains, how can this be utilized to motivate teachers in the future by the relevant authorities?

The results from our study also suggested that good interaction between teachers can help boost teachers' motivation to teach. It is also worth noting again that students' attitude and commitment was another main factor affecting motivation perceived by mathematics teachers. Lack of commitment and behavioral problems brought by students make teachers demotivated. Rashid and Dhindsa (2010) suggested that educational and professional development should include trainings on effective strategies in tackling students' difficult behavior. 


\section{Directions for further research}

Research provides evidence to demonstrate that the possibility of creating effective pedagogical practice is in the hands of the teacher (Li \& Stylianides, 2018; Li \& Tsai, 2017). Consequently, it is important for education leaders to find ways to maintain teachers in the profession and keep them motivated. More research is needed to investigate this particular area. In this study, only mathematics teachers who teach in government schools in Brunei Darussalam were involved, further research can include all kind of schools in the country to provide a more comprehensive view on the Bruneian teachers' motivation towards teaching. In addition, only questionnaires were used to collect data in the study, the use of interviews and classroom observations may also need to be adopted to allow richer and in-depth information.

\section{References}

Atkinson, E. S. (2000). An investigation into the relationship between teacher motivation and pupil motivation. Educational Psychology, 20(1), 45-57. https://doi.org/10.1080/014434100110371

Chiu, R. (2000). Does perception of pay equity, pay satisfaction, and job satisfaction mediate the effect of positive affectivity on work motivation? Social Behavior and Personality: An International Journal, 28(2), 177-184. https://doi.org/10.2224/sbp.2000.28.2.177

Dörnyei, Z., \& Ushioda, E. (2011). Teaching and researching motivation (2nd ed.). Harlow: Longman.

Ghenghesh, P. (2013). Job satisfaction and motivation - what makes teachers tick? British Journal of Education, Society \& Behavioural Science, 3(4), 456-466.

Guajardo, J. (2011). Teacher motivation: theoretical framework, situation analysis of save the children country offices, and recommended strategies (Research report). Retrieved from http://www.oxfamnovib.nl/Redactie/Downloads/English/SPEF/281-24\%20Teacher\%20Motiv ation\%20Report.pdf

Herzberg, F., Mausner, B., \& Snyderman, B. B. (2010). The motivation to work. USA: Transaction Publisher.

Li, H.-C. \& Stylianides, A. J. (2018). An examination of the roles of the teacher and students during a problem-based learning intervention: lessons learned from a study in a Taiwanese primary mathematics classroom. Interactive Learning Environments, 26(1), 106-117. https://doi.org/10.1080/10494820.2017.1283333.

Li, H.-C. \& Tsai, T.-L. (2017). What are "effective" pedagogical practices? From the perspectives of 21 st century student learning. In, Proceedings of the International Conference on Education, Psychology, and Social Sciences 2017 (ICEPS 2017), Bangkok, Thailand, 2-4 August 2017.2 Retrieve from http://iceps2017.globalconf.org/site/userdata/1127/Program/ICEPS-Full_Papers.pdf?m 
Li, H.-C. (2012). Implementing problem-based learning in a Taiwanese elementary classroom: a case study of challenges and strategies, Research in Mathematics Education, 14(1), 89-90. https://doi.org/10.1080/14794802.2012.657441.

Michaelowa, K. (2002). Teacher Job Satisfaction, Student Achievement, and the cost of Primary Education in Francophone Sub-Wirtschafts-Archiv. Hamburg Institute of International Economics.

Rasheed, M. I., \& Aslam, H. D. (2010). Motivational issues for teachers in higher education: a critical case of IUB. Journal of Management Research, 2(2), 1-23.

Rashid, M., \& Dhindsa, H. S. (2010). Science teachers' motivation to teach: intrinsic factors. International Journal of Science and Mathematics Education, 2(1), 16-31.

Sargent, T, \& Hannum, E. (2005). Keeping teachers happy: job satisfaction among primary school teachers in rural northwest China. Comparative Education Review, 49(2), 173-204. https://doi.org/10.1086/428100

Seniwoliba, A. J. (2013). Teacher motivation and job satisfaction in senior high schools in the Tamale metropolis of Ghana. Merit Research Journal of Education and Review, 1(9), 181-196.

Short, P. M., Greer, J. T., Melvin, W. M. (1994). Creating empowered schools: lessons in change. Journal of Educational Administration, 32(4), 38-52. https://doi.org/10.1108/09578239410069106

Urwick, J. D., Mapuru, P., \& Nkhoboti, M. (2005). Teacher motivation and incentives in Lesotho. Maseru: Lesotho College of Education.

\section{Copyright Disclaimer}

Copyright for this article is retained by the author(s), with first publication rights granted to the journal.

This is an open-access article distributed under the terms and conditions of the Creative Commons Attribution license (http://creativecommons.org/licenses/by/3.0/). 